\title{
DYNAMICS OF LAW ENFORCEMENT OF THE ISLAMIC CRIMINAL LAW IN ACEH IN THE INDONESIAN DEMOCRATIC SYSTEM
}

\author{
Rabiatul Adawiah ${ }^{1 *}$, Ihsan Kamaludin ${ }^{2}$ \\ ${ }^{1}$ Gadjah Mada University, Yogyakarta, Indonesia, e-mail: rabiatul.a@mail.ugm.ac.id \\ ${ }^{2}$ Gadjah Mada University, Yogyakarta, Indonesia, e-mail: ihsankamal95@,mail.ugm.ac.id \\ *Coreesponding Authors
}

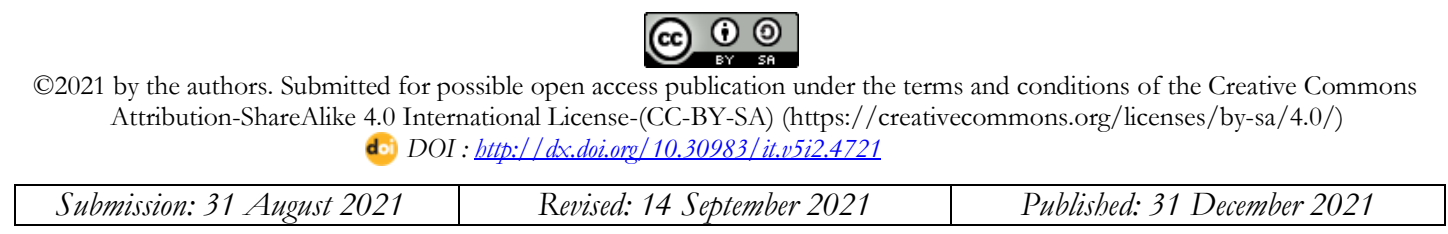

\begin{abstract}
This study focuses on analyzing the dynamics of the application of the Criminal Code (Qanun Jinayah) in the Aceh region. In the Pancasila democratic system run by the Indonesian state, the government guarantees the right of every citizen and belief group to manifest their teachings, but there are some areas that have the authority to enforce special policies such as Aceh which has ratified regional regulations based on Islamic law and the State supports the application of the rules. the. The method used in this study is descriptive qualitative research expected to be able to reveal qualitative information with description-analysis using the strategy used in this research is a case study. This research indicates that the implementation of Qanun Jinayah carried out in Aceh often results in differences of opinion because some parties consider that the application of the law overlaps with human rights which is usually implemented in democratic countries such as Indonesia, moreover the law also applies to non-Muslim residents who live in Aceh. However, there are also several parties who continue to support the implementation of the Qanun Jinayah to continue to be enforced because they have followed special rules ratified by the Government of Indonesia.
\end{abstract}

Keywords: Qanun jinayah, Human hights, Right violation.

\begin{abstract}
Abstrak
Penelitian ini berfokus untuk menganalisa dinamika penerapan Peraturan Tindak Pidana (Qanun Jinayah) di wilayah Aceh. Di dalam sistem demokrasi Pancasila yang dijalankan oleh negara Indonesia, pemerintah menjamin hak setiap warga negara maupun kelompok kepercayaan untuk memanifestasikan ajarannya, namun terdapat beberapa wilayah yang memiliki otoritas untuk memberlakukan kebijakan kbusus seperti Aceh yang telah mengesabkan peraturan daerah bedasarkan syariat Islam dan Negara mendukung penerapan aturan tersebutMetode yang digunakan di dalam penelitian ini adalah kualitatif deskriptif yang dimaksudkan untuk menganalisa topik. secara mendalam serta menggunakan strategi studi kasus. Penelitian ini mengindikasikan bahwa penerapan Qanun Jinayah yang dilakukan di Aceh sering kali menghasilkan perbedaan pendapat dikarenakan beberapa pihak menilai bahwa penerapan bukum tersebut tumpang tindib dengan bak asasi manusia, apalagi bukum tersebut juga berlaku bagi penduduk non-muslim yang tinggal di daerah Aceh. Meskipun demikian, terdapat juga beberapa pibak yang terus mendukung penerapan Qanun Jinayah tersebut untuk. dapat terus diberlakukan karena sudah mengikuti aturan khusus yang disabkan oleh Pemerintah Indonesia.
\end{abstract}

Kata Kunci: Qanun jinayah, Hak asasi manusia, Pelanggaran HAM

\section{Background}

Human rights are still the main discussion in Indonesian society, this happens because there are still many parties who experience discrimination related to freedom of religion and expression so that they try to claim justice to the

${ }^{1}$ Luisa Bravo, "We the Public Space. Strategies to Deal with Inequalities in Order to Achieve Inclusive and Sustainable Urban Environments," The Journal of Public Space state. ${ }^{1}$ This is because people think that the government is an official institution that is responsible for fulfilling the basic rights of its inhabitants. However, in practice, the fulfillment of these human rights values is often difficult to 
fulfill because there are some parties who still uphold the attitude of skepticism, especially if a discrimination and injustice occurs in other communities. ${ }^{2}$ This attitude of skepticism has also occurred in various regions in Indonesia since the implementation of human rights values. This is due to differences of opinion held by several groups that dominate a certain area, so that these values may not necessarily be enforced properly, as is the case with Aceh which enforces regional regulations based on Islamic law. ${ }^{3}$

So far, these regional regulations have been implemented since the days of the Iskandar Muda sultanate, mentioned in history as a form of the triumph of the Aceh government in implementing Islamic law. At that time, the Kingdom had recognized Islam as a religion and integrated the teachings of Islam in the seventeenth century Aceh kingdom. ${ }^{4}$ The existing integration is interpreted as "politicoreligious unity", there is a combination of Islam as an ideology and politics as the enforcement of the Islamic community. ${ }^{5}$ In its structure, Aceh has not only made Islam the majority religion but has become a pattern that dominates life. ${ }^{6}$ Law no. 11 of 2006 concerning the Government of Aceh, is a privilege for Aceh in the implementation of Islamic law in all aspects of life as outlined in the Qanun of Islamic Law. In Article 3 of Law no. 44 of 1999 concerning the implementation of the privileges of the province

2 Ben Stanford, "Power to the People? Public Spaces Protection Orders, Hybrid Law and Human Rights," SSRN Electronic Journal 12, no. 2 (2019): 234, https://doi.org/10.2139/ssrn.3442435.

3 Muhammad Ansor, "Merayakan Kuasa Agama," Akademika: Jurnal Pemikiran Islam 22, no. 1 (2017): 103, https://doi.org/10.32332/akademika.v22i1.562.

4 Abdul Rahman, "Sistem Pemerintahan Berbasis Syariat Islam di Indonesia (Studi Kasus Penerapan Qanun Jinayat di Pemerintah Provinsi Aceh)," KAIS Kajian Ilmu Sosial 2, no. 2 (2020): 100.

5 Amin Mudzakkir, "Islam dan Politik di Era Kontemporer," Epistemé: Jurnal Pengembangan Ilmu Keislaman 11, no. 1 (2016): https://doi.org/10.21274/epis.2016.11.1.31-48.

6 Yulia Susantri and Roni Hidayat, "Perda, Qanun, dan Perdasi dalam Sistem Hukum Nasional," Syiah Kuala of the Special Region of Aceh, it is stated that these privileges are carried out in the implementation of Islamic law, including; the right to religious life, customs, education, and the determination of regional policies implemented by ulama. ${ }^{7}$ But this was not welcomed by all Acehnese and what happened was rejection. ${ }^{8}$ As well as creating controversy in the community and over the last few years there have been violations of rights against Acehnese people due to Qanun Jinayah. Violation of these rights involves limiting the manifestation of public trust.

In the regional regulation regarding criminal acts (Qanun Jinayah), there are several laws related to acts that are not regulated by the Criminal Code," namely; Khalwat, Ikbtilath, Liwath, Musabaqah, Qadzaf, and Khamar. The provisions of the act which are included in the crime reap many pros and cons. Quoted in the BBC, Hidayatullah ${ }^{10}$ mentions that the first non-Muslim convicts in Aceh who were given a caning sentence in April 2016, then on 19 January 2018 at the Baitussalihin Mosque 10 people were declared to have violated the criminal Khamar which one of which nonMuslims received 36 lashes. ${ }^{11}$ The case of whip law against non-Muslims also received attention from various parties including the commissioner of KOMNAS HAM who saw that the imposition

Law Journal 4, no. 1 (2020): 41, https://doi.org/10.24815/sklj.v4i1.16595.

7 Ridwan Nurdin and Muhammad Ridwansyah, "Aceh, Qanun and National Law: Study on Legal Development Orientation," Samarah 4, no. 1 (2020): 111, https://doi.org/10.22373/sjhk.v4i1.6416.

8 Deni Setiawan et al., "Pro-Kontra Kebijakan Syariat Islam di Bumi Serambi Mekkah,” Dialektika: Jurnal Pemikiran Islam dan Ilmu Sosial 13, no. 1 (2020): 30.

${ }^{9}$ Mohammad Hashim Kamali, "Qanun Jinayat of Aceh, Indonesia," in Crime and Punishment in Islamic Law, 2019, 276-83,

https://doi.org/10.1093/oso/9780190910648.003.0024.

${ }^{10}$ Hidayatullah, "Dua Non Muslim di Aceh Pilih di Cambuk," 2018.

11 Acehkini, "Hukum CAmbuk di Aceh: Pernah Mendera 6 Warga Kristen dan 3 Buddha,” 2019. 
of Islamic law on non-Muslim communities set a precedent. ${ }^{12}$

In line with that, for the khalwat article, the article does not have a clear basis, ${ }^{13}$ because in a sexual relationship between two adults if it is done consensual or an agreement is not considered a crime and no one is harmed. If this is considered a crime, it will violate the privacy area, the law also has the potential to be discriminatory against women ${ }^{14}$ because in the Qanun Jinayah, if the accusation is not proven then the person who reports will receive a sentence and the evidence includes four direct witness. ${ }^{15}$

The study of Qanun Jinayah tends to analyze its understanding and position in national law. In terms of understanding and position of Qanun Jinayah in society, ${ }^{16}$ explained that many Acehnese responded with negative responses so they did not follow the regulation. ${ }^{17}$ In line with that, there is also resistance, ${ }^{18}$ said that there are pros and cons who think that the law is not optimal and seems selective so the law is not

12 Isyana Artharini, "Hukuman Cambuk Atas NonMuslim di Aceh, Dapat 'Menjadi Preseden dan Meluas," www.bbc.com, 2016.

13 Ahmad Nurozi and Dadan Muttaqien, "The Effectiveness of Crime Prevention with Corporal Punishment in Nanggroe Aceh Darussalam," Millah: Jurnal Studi Agama 20, no. 2 (2021): 228, https://journal.uii.ac.id/Millah/article/view/14771.

14 Faradilla Fadlia and Ismar Ramadani, "The Qanun Jinayat Discriminates Against Women (Victims of Rape) in Aceh, Indonesia," Journal of Southeast Asian Human Rights 2, no. 2 (2018): 450, https://doi.org/10.19184/jseahr.v2i2.8358.

15 Yogi Febriandi, Muhammad Ansor, and Nursiti, "Seeking Justice through Qanun Jinayat: The Narratives of Female Victims of Sexual Violence in Aceh, Indonesia," Qudus International Journal of Islamic Studies 9, no. 1 (2021): 118, https://doi.org/10.21043/QIJIS.V9I1.8029.

16 Edi Yuhermansyah and Meri Andani, "Tanggapan Masyarakat Kecamatan Pulau Banyak Terhadap Pemberlakuan Qanun Nomor 6 Tahun 2014 Tentang Hukum Jinayat," Legitimasi: Jurnal Hukum Pidana dan Politik Hukum 7, no. 1 (2018): 43, https://doi.org/10.22373/legitimasi.v7i1.3964.

${ }^{17}$ Andi Muhammad Asrun, Abdu Rahmat Rosyadi, and Yennie K. Milono, "Mempertanyakan Legalitas Qanun Aceh: Sesuaikah dengan Sistem Peraturan Perundang- implemented properly. ${ }^{19}$ As part of Indonesia, this tends to lead to the intensity of legal differences between regions that also deal with criminal acts. ${ }^{20}$ On the other hand, Nurdin emphasized that there is a uniqueness of the Qanun Jinayah that can be used as a stimulus for universal law, the privileges given should not be interpreted as a differentiator but as a unitary subsystem. $^{21}$

So far, there have been several studies conducted by experts in order to understand the implementation of the implementation of Islamic law in Aceh. Hasnil Basri Siregar stated that the law enforced in the Aceh region cannot be separated from the history of the struggle of the Acehnese people who in fact are Muslim. moreover, these Islamic values are firmly held and become a strong culture so that the Acehnese, represented by several elders, propose to the Indonesian government to be given the freedom to use the religious system in their area. ${ }^{22}$ Furthermore, Hasnil also emphasized that the application of religious values in the Aceh region

Undangan,” Kanun Jurnal Ilmu Hukum 21, no. 2 (2019): 291, https://doi.org/10.24815/kanun.v21i2.12632.

18 Junaidi Junaidi, Muhammad Rusdi Bin Muhammadiah, and Muhazir Muhazir, "Revitalisasi Penerapan Qanun Nomor 6 Tahun 2014 Tentang Hukum Jinayat di Kota Langsa Aceh," Al-Manabij: Jurnal Kajian Hukum Islam 14, no. 1 (2020): 147-60, https://doi.org/10.24090/mnh.v14i1.3261.

${ }^{19}$ Ahyar Ahyar, "Aspek Hukum Pelaksanaan Qanun Jinayat di Provinsi Aceh," Jurnal Penelitian Hukum De Jure 17, no. 2 (2017): 131-154, https://doi.org/10.30641/dejure.2017.v17.131-154.

20 Cut Maya Aprita Sari, "Pro dan Kontra Implementasi Qanun Syariat Islam di Aceh," Jurnal Review Politik $06, \quad$ no. 01 (2016): 76, https://www.researchgate.net/profile/Cut-Maya-ApritaSari/publication/342831406_Pro_dan_Kontra_Implemen tasi_Qanun_Syariat_Islam_di_Aceh/links/5f07e31c92851 c52d6268daf/Pro-dan-Kontra-Implementasi-QanunSyariat-Islam-di-Aceh.pdf.

21 Ridwan Nurdin, "Kedudukan Qanun Jinayat Aceh dalam Sistem Hukum Pidana Nasional Indonesia," Miqot: Jurnal Ilmu-Ilmu Keislaman 42, no. 2 (2019): 358, https://doi.org/10.30821/miqot.v42i2.542.

${ }^{22}$ Hasnil Basri Siregar, "Islamic Law in a National Legal System: A Study on the Implementation of Shari'ah in Aceh, Indonesia," Asian Journal of Comparative Law 3, no. 1 (2008): 1-26, https://doi.org/10.2202/1932-0205.1056. 
also resulted in various types of amalgamation of democratic law and Islamic law which often differed from each other. This is because the applied religious values not only regulate people's behavior in the public sphere but also various activities in the private sphere. ${ }^{23}$

Feener's findings about the contestation of religious values and the globalization system of Western values also help the author to analyze how the social dynamics that occurred in Acehnese society began with the hegemonic war to the implementation of the values of the teachings adopted. ${ }^{24}$ Furthermore, David Kloss emphasized that the application of Sharia law in a democratic Indonesian state is an application of democratic principles which are officially expressed in state institutions. Moreover, slogans for the return of Sharia values continue to be presented in the community so that there are some parties who are not happy with the presence of the Aceh government over the hegemonic war that occurred.

This study uses qualitative-descriptive methods that attempt to dig deep information with interview and observation techniques. The author begins this research by observing the literature that discusses the dynamics that occur in Acehnese society. The author also searches for information through data analysis of several sources on official websites owned by several official institutions such as the government or non-governmental organizations.

${ }^{23}$ Hasnil Basri Siregar, "Lessons Learned from the Implementation of Islamic Shari'ah Criminal Law in Aceh, Indonesia," Journal of Law and Religion 24, no. 1 (2009): 145.

${ }^{24}$ R. Michael Feener, "Social Engineering through Sharîa: Islamic Law and State-Directed Da'wa in Contemporary Aceh," Islamic Law and Society 19, no. 3 (2012): 275-311, https://doi.org/10.1163/156851911X612581.

25 Black Donal, The Behaviour of Law (New York: Academic Press, 1976), 23.

26 Prawitra Thalib, "Pemahaman Terhadap Pemberlakuan Hukum Islam di Indonesia," Halu Oleo Law Review 2, no. 1 (2018): 377 , https://doi.org/10.33561/holrev.v2i1.4196.

\section{The Dynamic of Law in Aceh}

The enactment of Islamic law in Aceh reaps many contradictions, not a few practitioners and academics criticizing the law. Related to the value of justice and human rights protection for the community. Public concern over the enactment of Qanun always refers to "the regulation is only intended for small or minority groups". This is based on the theory of legal stratification by Donald Black 1659, that the law is like water, which always seeks and flows in a lower place. ${ }^{25}$ In reality, different interests have a significant impact on the enactment of a law. ${ }^{26}$ Islam imposes normative values in the lives of individuals and groups for its adherents, while the state is obliged to impose values that are acceptable to all citizens.

In connecting with those two situations between Islamic Law in Aceh, Qanun as the official law of Islamic law in Aceh was born from the legal mechanism in the Aceh People's Representative Council (DPRA). ${ }^{27}$ Meanwhile, the enactment drew debate between the Aceh government and the Aceh People's Representative Council also occurred. ${ }^{28}$ So that the enactment of Islamic law in Aceh is not necessarily able to accommodate all the values embraced by a plurality society especially when the Qanun against the democratic values on human rights.

There are nine Qanuns that were born and implemented through Islamic law, ${ }^{29}$ The Qanuns are: 1) Aceh Qanun No. 1 of 2014 concerning

${ }^{27}$ Putri Maulina, "Relasi Kekuasaan dalam Wacana Penerapan Qanun Jinayat di Aceh," Source: Jurnal Ilmu Komunikasi 3, no. 2 (2018): 248, https://doi.org/10.35308/source.v3i2.658.

${ }^{28}$ Zaki Ulya, "Dinamika Penerapan Hukum Jinayat Sebagai Wujud Rekonstruksi Syari'at Islam di Aceh,” Jurnal Rechts Vinding: Media Pembinaan Hukum Nasional 5, no. 1 (2016):

139,

https://www.rechtsvinding.bphn.go.id/ejournal/index.ph $\mathrm{p} / \mathrm{jrv} /$ article/view/9.

${ }^{29}$ Asrun, Rosyadi, and Milono, "Mempertanyakan Legalitas Qanun Aceh: Sesuaikah dengan Sistem Peraturan Perundang-Undangan.” 
public road levies, 2) Aceh Qanun No. 3 of 2014 concerning certain licensing fees, 3) Aceh Qanun No. 4 of 2014 concerning accountability for the implementation of the revenue and expenditure budget in Aceh for the 2013 fiscal year, 4) Aceh's Qanun No. 6 of 2014 concerning the law of Jinayah, 5) Aceh Qanun No. 7 of 2014 concerning employment, 6) Aceh Qanun 8 of 2014 concerning the principles of Islamic law, 7) Aceh's Qanun 9 of 2014 concerning the establishment of the Aceh Sharia Bank, 8) Aceh's Qanun 10 of 2014 concerning amendments to Aceh Qanun 1 of 2008 concerning management Aceh's finances, 9) Aceh Qanun No. 11 of 2014 concerning the implementation of education.

Of the several Qanuns mentioned earlier, the Jinayah Qanun is a regional regulation that has caused a lot of controversy regarding its legality and implementation. ${ }^{30}$ The Jinayah Qanun when viewed from the national legal system, has two positions. Namely as a regional regulation that is the same between provinces and as a system formed to regulate the implementation of Islamic law as a form of special autonomy. ${ }^{31}$ Qanun has been ratified by the Aceh government to implement Islamic law in the lives of Acehnese people. As in the regional regulation formulated in Qanun Jinayah ${ }^{32}$ Number 6 of 2014 Article $3^{33}$,

30 Junaidi, Bin Muhammadiah, and Muhazir, "Revitalisasi Penerapan Qanun Nomor 6 Tahun 2014 Tentang Hukum Jinayat di Kota Langsa Aceh.”

${ }^{31}$ Endri Ismail, "Analisis Yuridis Terhadap Legalitas Qanun Aceh No. 6/2014 Tentang Hukum Jinayat," Kanun Jurnal Ilmu Hukum 20, no. 1 (2018): 128, https://doi.org/10.24815/kanun.v20i1.9625.

${ }^{32}$ Madiasa Ablisar, "Relevansi Hukuman Cambuk Sebagai Salah Satu Bentuk Pemidanaan dalam Pembaharuan Hukum Pidana," Jurnal Dinamika Hukum 14, no. 2 (2014): 279, https://doi.org/10.20884/1.jdh.2014.14.2.296. 2014," n.d.

33 Pemprov Aceh, "Qanun Jinayat No.6 Tahun

${ }^{34}$ Selvia Junita Praja and Wia Ulfa, "Implementasi Qanun Nomor 6 Tahun 2014 Tentang Hukum Jinayat di Kota Banda Aceh Provinsi Aceh," Jurnal Kebijakan Pemerintaban 3, no.1 (2020): 12, https://doi.org/10.33701/jkp.v3i1.1071.

35 Rahmiati Rahmiati, "Politik Hukum Terhadap Qanun Nomor 6 Tahun 2014 Tentang Hukum Jinayah," the scope of acts that are considered criminal or Jarimah has been regulated. Like Khalwat, is an act carried out in a closed or hidden place between two people of different sexes without marriage ties with a willingness that leads to adultery, ${ }^{34}$ Ikbtilah, is an act of making out like making out, touching, hugging, and kissing between two types who are not husband and wife willingly either in public or closed places. ${ }^{35}$ Liwath or Gay sexual act of a man with another man willingly. ${ }^{36}$ Mushahaqah or Lesbian, sexual acts among women willingly. ${ }^{37}$ Qadraf, namely accusing someone of committing adultery without carrying sanctions of at least four people. ${ }^{38}$ The last one is Khamar or alcohol, which produces, stores, sells and even drinks. ${ }^{39}$

The presence of Qanun Aceh No. 6 of 2014 is a form of effort to provide for vacancies in the Criminal Code, but in this case, it does not conflict with existing provisions and does not conflict with the Criminal Code itself. But in reality, there are criminal acts listed in the Criminal Code but re-arranged in the Qanun. So, this creates legal uncertainty in Indonesia ${ }^{40}$, there is a potential for dualism in the application of the criminal law of Qanun Jinayah in Aceh. Where in a region it is necessary to consider the plurality of society without limiting the rights of every

SASI 26, no. 1 (2020): https://doi.org/10.47268/sasi.v26i1.209.

36 - - Misran, "Sosialisasi Qanun Jinayat Aceh No. 6 Tahun 2014 Pada Madrasah Aliyah Blangkejeren Kabupaten Gayo Lues," Dusturiyah: Jurnal Hukum Islam, Perundang-Undangan dan Pranata Sosial 9, no. 1 (2019): 12, https://doi.org/10.22373/dusturiyah.v9i1.4365.

37 Junaidi, Bin Muhammadiah, and Muhazir, "Revitalisasi Penerapan Qanun Nomor 6 Tahun 2014 Tentang Hukum Jinayat di Kota Langsa Aceh."

38 Siti Sahara and Meta Suriyani, "Efektifitas Penghukuman Bagi Pelaku Maisir (Perjudian) di Kota Langsa," Jurnal Hukum Samudra Keadilan 13, no. 1 (2018): 118-38, https://doi.org/10.33059/jhsk.v13i1.697.

39 Mahdi, "Sistem Hukum Penegakan Qanun Jinayah di Aceh,” Media Syariab XIII, no. 2 (2011): 187.

${ }^{40}$ Zainuddin and Sahban, "Problematics of Jinayat Qanun Implementation in Nanggroe Aceh Darussalamn Community," Tadulako Law Review 3, no. 1 (2018): 227, http://jurnal.untad.ac.id/index.php/TLR. 
citizen. Where it can provide space for every citizen to carry out the law of life without ignoring other legal interests. In the context of a pluralistic Indonesian society, the law always lives and develops in line with the dynamics of community development, both forming a sociocultural and political perspective. ${ }^{41}$ However, in this case, the culture in Indonesia is generally influenced by patriarchal culture, resulting in a lot of violence against women, as previously mentioned that through Qanun Jinayah, women have the potential to get sexual violence. So that the regulation is considered to have limited women's access to justice. Regarding this matter, the Qanun Jinayah is a product of religious conservatism. ${ }^{42}$ This perspective is commonly found in non-pro-women patriarchal cultures. ${ }^{43}$

In line with that, sharia courts generally have broader scope of authority than other courts $^{44}$. In this case, the authority is to examine and decide and adjudicate cases in the first level and appeal. Basically, sharia courts are authorized and have powers that cover all aspects of the law that require settlement through the judiciary. In line with the implementation of Qanun Jinayah, Wilayatul hisbah is an Institution that conveys to the public about the applicable regulations, as well as the submission to comply with the rules

41 L.A. Krisna et al., "The Urgency of Harmonization of Offense Types in The Qanun Jinayat As An Effort to Avoid Dualism In Application of Law," Russian Journal of Agricultural and Socio-Economic Sciences 112, no. 4 (2021): 15-21, https://doi.org/10.18551/rjoas.202104.02 .

42 Simon Butt, "Religious Conservatism, Islamic Criminal Law and the Judiciary in Indonesia: A Tale of Three Courts," Journal of Legal Pluralism and Unofficial Law 50, no. 3 (2018): https://doi.org/10.1080/07329113.2018.1532025.

43 Fatima Seedat, "Sexual Economies of War and Sexual Technologies of the Body: Militarised Muslim Masculinity and the Islamist Production of Concubines for the Caliphate," Agenda 30, no. 3 (2016): 25-38, https://doi.org/10.1080/10130950.2016.1275558.

44 Efa Laela Fakhriah, "Kewenangan Mahkamah Syar'iyah di Aceh Dihubungkan dengan Sistem Peradilan di Indonesia," Jurnal Ilmu Hukum 12, no. 2 (2013): 23-36, https://jih.ejournal.unri.ac.id/index.php/JIH/article/view /1814\%0Ahttps://jih.ejournal.unri.ac.id/index.php/JIH/ article/download/1814/1785. that have been imposed (law enforcement) ${ }^{45}$ and respond and follow up on community complaints then report it to the police.

This is a regulation that does not look at the background of the people who do it, ${ }^{46}$ where every citizen in Aceh is required to follow the regulation ${ }^{47}$. However, as it is known that people in Aceh are not only Muslim, there are various beliefs or beliefs. In this case, as happened to Christian women's institutions, which are a minority group in Aceh, they face a critical situation. Even though they are independent and feel they should not be easily subjugated in a public space which is the domination of minority religious values and identities. ${ }^{48}$ There are provisions that apply to regions in applying Islamic law, that anyone who lives and is domiciled, Muslim or non-Muslim in Aceh is bound by the applicable criminal law. ${ }^{49}$ In reality, the minority group reaps the limitations of space and movement to express themselves in the public sphere. As the results of the interview by that "as a follower of a religious minority, it is difficult to be able to develop or actualize themselves in Aceh"50.

In law enforcement Qanun Jinayah, it can't be separated from the role of the local community. Information about the treatment of

45 Wike Anggraini and Nella Safira, "Penegakan Syariat Islam di Kota Banda Aceh - Kinerja Wilayatul Hisbah," Jurnal Tatapamong 12, no. 1 (2019): 75-94, https://doi.org/10.33701/jurnaltatapamong.v1i2.1153.

46 Tempo, "Qanun Jinayat Aceh Juga Berlaku Untuk Non-Muslim,” 2014.

${ }^{47}$ Muhammad Irham, "Kedudukan Syariat Islam di Nanggroe Aceh Darussalam (NAD) Dalam Sistem Hukum Nasional," Jurnal Mentari 12, no. 1 (2009): 34.

48 Muhammad Ansor and Yaser Amri, "Being Christians in the Acehnese Way: Illiberal Citizenship and Women's Agency in the Islamic Public Sphere," Journal of Indonesian Islam 14, no. 1 (2020): 81, https://doi.org/10.15642/JIIS.2020.14.1.77-112.

49 Sudirman Suparmin, "Hukuman Cambuk Terhadap Non Muslim Pelaku Jarimah di Nanggroe Aceh Darussalam," Analytical Islamica 6, no. 2 (2017): 147-54.

50 Husni Mubarrak and Intan Dewi Kumala, "Diskriminasi Terhadap Agama Minoritas: Studi Kasus di Banda Aceh," Seurune Jurnal Psikologi Unsyiah 3, no. 2 (2020): 42-60, https://doi.org/10.24815/s-jpu.v3i2.17553. 
Jinayah comes from the community. However, there are times when society plays a role beyond its capacity, in this case 'vigilante or social sanction'. Even the cases found, not up to the authorities, but resolved at the place of the case. Basically, Aceh also has an Indigenous judiciary that regulates the authority in resolving cases that occur in its territory. ${ }^{51}$ In this case the authority of the customary judiciary is supported by a number of laws and regulations. ${ }^{52}$ It's just that every customary law imposed on the perpetrator is not the same as the law that applies in Qanun Jinayah. Such as Khalwat, perpetrators married, fines of two goats and monetary fines. In this case, it is mentioned that there are two legal instruments, the laws of the country and the laws of the people. ${ }^{53}$

Broadly speaking, these regulations apply to all Acehnese people, there are no restrictions, Aceh has its own context regarding applicable regional regulations. This is based on the real facts of the application of Islamic criminal law in the era of a unique state, it can be seen that Qanun Jinayah is more described as a legal construction of sharia. ${ }^{54}$ In this case, the Qanun that was formed, instead of being enforced for the interests and welfare of the community, actually became a tool to violate human rights that belonged to humans.

\section{The Human Rights Perspective}

Based on the applicable Jinayah Qanun, the existing and regulated punishment is whipping. Regarding the response of several Islamic organizations in Indonesia that they do not actively encourage and ask for the caning

51 Mubarrak and Kumala.

52 Nur Rochaeti and Rahmi Dwi Sutanti, "Kontribusi Peradilan Adat dan Keadilan Restoratif dalam Pembaruan Hukum Pidana di Indonesia," Masalab-Masalah Hukum 47, no. 3 (2018): 198-201, https://doi.org/10.14710/mmh.47.3.2018.198-214.

53 Rahmiati, "Politik Hukum Terhadap Qanun Nomor 6 Tahun 2014 Tentang Hukum Jinayah.”

${ }^{54}$ Nurdin, "Kedudukan Qanun Jinayat Aceh dalam Sistem Hukum Pidana Nasional Indonesia,” 359. punishment to be applied, ${ }^{55}$ this has been regulated in the applicable regional regulation ${ }^{56}$, namely whipping, is a punishment principal for a criminal act, the amount has also been determined, Khalwat, is threatened with 10 lashes, for those who provide and promote khalwat jarimah get 15 lashes. Ikbtilah, threatened with 30 lashes, for those who facilitate and promote get 45 lashes. Liwath, threatened 100 lashes, who do with a child then 200 lashes. Mushahaqah, is threatened with 100 lashes, if you do it with a child then 200 lashes, Qadraf, is threatened with 80 lashes and Khamar, for those who drink 40 lashes, for those who keep, sell 60 lashes, buy and give 20 lashes as a gift. If the children intentionally include 80 lashes. Regarding this caning, the Legal Aid Institute ( $\mathrm{LBH})$ considers the implementation of this punishment a blasphemy of human rights enforcement in Indonesia, based on this belief, LBH has been monitoring and documenting the media throughout 2016 regarding the implementation of the practice of whipping which is considered a violation of human rights.

As for the implementation, there are differences with other countries, such as in Malaysia, which carries out the caning in a closed place or even in a prison that cannot be witnessed by the public, by tying the convict's hands to a pole that has been determined in a half-faced position $^{57}$ while the caning in Aceh was carried out in an open place where the public could attend. On the other hand, the convict has the potential to die while serving the sentence. So that when the convict dies, the body is returned to the family or the prosecutor who will bury it. ${ }^{58}$

\footnotetext{
${ }^{55}$ M. Syafi'ie, "Pemikiran Organisasi Islam Tentang Penerapan Hukum Pidana Islam: Tinjauan Hukum Hak Asasi Manusia," Undang: Jurnal Hukum 2, no. 2 (2020): 230, https://doi.org/10.22437/ujh.2.2.225-264. 2014.”

56 Pemprov Aceh, "Qanun Jinayat No.6 Tahun

57 Ablisar, "Relevansi Hukuman Cambuk Sebagai Salah Satu Bentuk Pemidanaan dalam Pembaharuan Hukum Pidana," 284.

${ }^{58}$ Dian Agung Wicaksono and Ola Anisa Ayutama, "Pengaturan Hukum Cambuk Sebagai Bentuk Pidana
} 
The impact that occurs is that the convict experiences psychological disorders, Komnas HAM regrets the implementation of the caning because it is clear that it is contrary to the principle of human rights which degrades human dignity.

The law that applies in the Qanun Jinayah is a refinement of several provisions that have been in force previously. The application of caning which is a right violation will be analyzed based on the perspective of religious rights and manifesting their beliefs. ${ }^{59}$ The power contained in the Qanun Jinayah indirectly has repressive power to force non-Muslims to submit and obey the provisions of the Shari'a of other religions that are not their religion. This means that this is contrary to the constitution of the Republic of Indonesia which guarantees freedom of religion in which the public cannot be punished based on religious teachings other than the religion that is believed and obeyed. ${ }^{60}$

Since the ratification of the Qanun Jinayah, the caning sentence has broken up controversy, this stems from the National Alliance for Freedom of Religion or Belief (AKKBB), that the imposition of punishment for actions committed by the community is a violation of human rights, including the right to freedom of religion, manifesting beliefs and rights. freedom of society from cruel punishments that are torture. ${ }^{61}$ Accordingly, Human Rights Watch $^{62}$ explained that this regional regulation limits the basic rights of people in Aceh to freedom of expression, privacy and freedom of religion. It also said that discriminating against same-sex relationships was a major setback, saying flogging

dalam Qanun Jinayat," Majalah Hukum Nasional 48, no. 1 (2018): 33, https://doi.org/10.33331/mhn.v48i1.111.

59 Zainal Abidin Bagir, Membatasi Tanpa Melanggar (Yogyakarta: Center for Religious and Cross-Cultural Studies, 2019), 21.

${ }^{60}$ Zainuddin and Sahban, "Problematics of Jinayat Qanun Implementation in Nanggroe Aceh Darussalamn Community."

${ }^{61}$ detiknews, "AKKBB: Pengesahan Qanun Jinayat di NAD Melanggar HAM,” 2009. was a punishment that should have been abandoned since the Middle Ages.

In this case it can be emphasized that the state is an institution whose duty is to respect, protect and fulfil, while individuals or communities are right holders rather than the obligations and responsibilities of the state. ${ }^{63}$ In Indonesia, there has been a tug of war between patterns of diversity built on ideals/texts and patterns of diversity in historical reality/contexts. In this case, Islam or religion basically deserves to be interpreted dynamically based on the challenges and demands of human reality. So, when faced in the context of Islam, what is needed is reformulation that leads to a multidimensional approach to re-relevance Islamic teachings to the interests of human benefit. In addition, there is no strong justification for the implementation of Qanun Jinayah, including the problem of defining private and public spaces. It is also mentioned in "Limitations on the Freedom of Religion or Belief"by $\mathrm{T}$. Jeremy Gunn. He mentions the restriction clause provided in $\mathrm{UDHR}^{64}$ which identifies conditions under which a state or government can legally limit the exercise of rights, also guaranteeing older people.

From a human rights point of view, there is a forum internum domain, where humans have the right to defend their religion or belief, this is a non-derogable right. Whereas in the external forum, humans can be limited in some ways when manifesting these beliefs. In the discourse of human rights, what must be understood is the internal forum and the external forum to understand freedom properly because freedom is

62 Hrw, "Indonesia: Aceh's New Islamic Laws Violate Rights,” 2014.

${ }^{63}$ Marzuki Suparman, Politik Hukum dan Hak Asasi Manusia (Jakarta: Penerbit Erlangga, 2014), 100.

${ }^{64}$ The General Assembly, "Universal Declaration of Human Rights (Chuukese)," Asia-Pacific Journal on Human Rights and the Law 8, no. 1 (2007): 101-6, https://doi.org/10.1163/157181507782200222. 
more than just a choice, freedom from religion is a logical element of freedom of religion or belief itself, because it follows from the nature of the right to freedom. In addition, Bielefeldt underlines the term widely used in international law to identify the 'internal' realm of belief that the government has no regulations to limit it, it is the "forum internum", whereas the external realm that embodies belief, which may be restricted by the state, is identified as " external forums". ${ }^{65}$

Based on the forum domains that have been mentioned, the rules in Qanun Jinayah which state that 0659 Khamr is one of the things that are detrimental in Aceh, Islam considers and believes Khamr as one of the factors to be considered in the safety of religion, thoughts, life, property, and lineage. In this case, in 2021, three non-Muslims were sentenced to 40 lashes with alcohol or khamar, two of whom were not Acehnese but North Sumatran. In addition, in the case of Liwath or gay, the couple was sentenced to 80 lashes. Furthermore, there were 11 people who received caning sentences in Aceh Tamiang, the implementation was attended by the head of the Islamic law service. ${ }^{66}$ Based on the caning sentence, Amnesty International ${ }^{67}$ responded that such punishment is inhumane and degrading and torturing humans. Where a person's right to privacy has been violated by limiting the manifestation of his belief, and no one deserves to undergo this kind of cruelty. Moreover, the sentence must be based on international

\footnotetext{
${ }^{65}$ Heiner Bielefeldt, "Misperceptions of Freedom of Religion or Belief," Human Rights Quarterly 35, no. 1 (2013): 33-68, https://doi.org/10.1353/hrq.2013.0009.

66 Humas, "11 Terdakwa Pelanggar Syariat Aceh Tamiang Dicambuk,” 2021.

${ }^{67} \mathrm{dw}$, "Dua Orang Pingsan Saat Eksekusi Cambuk di Aceh, Amnesty: Kejam dan Tidak Manusiawi,” 2019.

68 Cempaka, Ali Abu Bakar, and Badrul Munir, "Sanksi Bagi Pelaku Zina," Petita: Jurnal Kajian Ilmu Hukum dan Syariah 3, no.2 (2020):176-200, https://doi.org/10.22373/petita.v3i2.54.

69 nadia Maulida Zuhra, "Penerapan Hukuman Cambuk Bagi Pelaku Pelecehan Seksual dalam Perkara Jinayat Dihubungkan dengan Jaminan Akan Hak Asasi Manusia Atas Rasa Aman dan Perlindungan Bagi Korban,"
}

standards and Indonesia's human rights obligations under the constitution.

The people of Aceh say that the implementation of the caning law is only targeted and applied to the lower classes, while officials are said to be above the law. The existing punishment takes care of all personal actions such as liwath and actions that are considered criminal by the Aceh government. that every act gets a commensurate or commensurate recompense, based on the verse mentioned in the Qur'an, the punishment of whipping only speaks in the context of adultery, not in other cases. ${ }^{68}$ However, this cannot be done if both parties accept and have mutual agreement. because the regulation of punishment is not solely on the punishment of caning but there are fines and imprisonment as an alternative form. ${ }^{69}$

Based on the existing dynamics, society is demanded by social changes that provide changes in the value system and law. In the theory of Max Weber and Emile Durkheim that "the law is a reflection of the solidarity that exists in society", ${ }^{70}$ the occurrence of these changes is caused by two factors, namely; increasing population and decreasing population, new discoveries and conflicts that exist in the area, this is based on internal factors, while external factors, caused by the environment, influences from other cultures and wars. ${ }^{71}$ At the same time, regarding the beliefs that exist in an area with changing value systems and laws, ${ }^{72}$ states that it is important to ensure that every criterion used to define religion or

DiH: Jurnal Ilmu Hukum 16, no. 2 (2020) 259-70, https://doi.org/10.30996/dih.v16i2.3668.

${ }^{70}$ Hasnul Arifin Melayu et al., "Syariat Islam dan Budaya Hukum Masyarakat di Aceh," Media Syari'ah: Wabana Kajian Hukum Islam dan Pranata Sosial 23, no. 1 (2021): 60, https://doi.org/10.22373/jms.v23i1.9073.

71 I Ismawardi, "Syari'at Islam dalam Lingkup Keberagaman Masyarakat Aceh," Bidayah: Studi Ilmu-Ilmu Keislaman 12, no. 2 (2019): 165-82, http://ejournal.staindirundeng.ac.id/index.php/bidayah/a rticle/view/181.

72 Bielefeldt, "Misperceptions of Freedom of Religion or Belief." 
belief remains universal and For this reason, it is formal enough, that it is possible to include different manifestations of existing beliefs and the realistic or ethical practice of a belief. This includes the right to religion or belief. The rights of religion or belief that exist then intersect with freedom of expression and the right to privacy.

However, one could hardly deny that the relationship between Islam as a religion and human rights is complicated. It gave the central role of religion in human life, unnecessary limitations on its expression are attacks on human freedom itself. ${ }^{73}$ These problems do not derive from Islamic verse but have to do with the Islamic sharia, or more precisely, with traditional or fundamentalist interpretation of the sharia by which the latter is rendered a comprehensive system of politically enforceable normative regulations. It mentions as Islamization of human rights, this is to say that such a dogmatic type of reference to a divine foundation of human dignity leads to concept a dignity that, in sharp contradiction to article 1 of the Universal Declaration of Human Rights, serve as a vindication of human inequality rather than justifying universal equality of all human beings in dignity and freedom. ${ }^{74}$

Regarding religion, freedom of religion or belief is guaranteed by law, but sometimes the common problem is that the government does not know what can be and cannot be restricted. At the same time, there is a growing fear that religion is subtly passed on to one's private life, under the pretext of plurality. religious doctrines and worldviews. As in the International Covenant on Civil and Political Rights in Article 2 that each

73 Brendan Sweetman, "Equality, Freedom and Religion," The Philosophical Quarterly, 2016, pqw033, https://doi.org/10.1093/pq/pqw033; Heru Permana Putra and Desi Syafriani, "Otonomi Daerah dan Pengaruhnya Terhadap Kebijakan Daerah Bernuasa Syariah di Kota Padang," Islam Transformatif: Journal of Islamic Studies 3, no. 2 (2019): 136, https://doi.org/10.30983/it.v3i2.2417.

74 Heiner Bielefeldt, 'Western' versus 'Islamic' Human Rights Conceptions? A Critique of Cultural state in this treaty undertakes to respect and ensure to all individuals in its territory and subject to its jurisdiction the rights recognized in this treaty, without distinction in any form, such as race, color, gender, language, religion, national or social political origin, property, birth or status.

In addition, Article 18 of the UDHR, ${ }^{75}$ also article 18 of the International Covenant on Civil and Political Rights mentions that freedom of religion or belief is a universal right which all human beings have a claim to just because of their inherent dignity as 'members of the human family'. Equally important, given its liberating thrust as a right to freedom, it aims at empowering people to realize their potential of responsible agency and thus freely find their ways in the field of religion or belief, as individuals and together with others. In addition, in keeping with its universalistic nature, freedom of religion or belief must be respected and implemented in a non-discriminatory manner, since equality in human dignity inevitably implies equality of all in their basic right. ${ }^{76}$

\section{Conclusion}

The existing regional regulations in Aceh are well known to the general public-not only Indonesia. In fact, the issue of Aceh's Sharia regional regulations (Qanun) has attracted the attention of many experts from other countries to explore it. This is based on the dominance of Religion in Regional Regulations (Qanun) in Aceh which turns out to have an impact on discrimination and rights violations, where the Qanun is applied to all communities in Aceh, including caning punishments for criminals, that the Aceh government cannot map the domain

Essentialism in the Discussion on Human Rights," Political Theory 28, no. 1 (2000): 90-121, https://doi.org/10.1177/0090591700028001005.

75 Assembly, "Universal Declaration of Human Rights (Chuukese)."

${ }^{76}$ Heiner Bielefeldt, "Freedom of Religion or Belief - A Human Right under Pressure," Oxford Journal of Law and Religion 23, no. 2 (2012): 12 , https://doi.org/10.1093/ojlr/rwr018. 
rights of every society. Freedom to manifest a belief or belief is guaranteed by law, which is basically known that a law can consider the plurality of society without limiting the rights of every citizen especially non-muslim in democratic country such as Indonesia.

The issue related to the dynamics of the implementation of the Qanun rules imposed in Aceh also illustrates that in the application of democratic values in Indonesia that uphold the aspect of individuality freedom can contradict with the majority agreement so that minority groups get various treatments based on the values of other religions. This phenomenon has also become an illustration for the central government to be able to pay attention to the basic rights of minority citizens living in areas that apply the law of a religion so as not to violate the values of human rights.

\section{References}

Ablisar, Madiasa. "Relevansi Hukuman Cambuk Sebagai Salah Satu Bentuk Pemidanaan dalam Pembaharuan Hukum Pidana." Jurnal Dinamika Hukum 14, no. 2 (2014): 22-37. Https://Doi.Org/10.20884/1.Jdh.2014.14. 2.296 .

Acehkini. "Hukum Cambuk di Aceh: Pernah Mendera 6 Warga Kristen dan 3 Buddha," 2019.

Ahyar, Ahyar. "Aspek Hukum Pelaksanaan Qanun Jinayat di Provinsi Aceh." Jurnal Penelitian Hukum De Jure 17, no. 2 (2017): 131.

Https://Doi.Org/10.30641/Dejure.2017.V 17.131-154.

Anggraini, Wike, And Nella Safira. "Penegakan Syariat Islam di Kota Banda Aceh - Kinerja Wilayatul Hisbah." Jurnal Tatapamong 12, no. 1 (2019): 75-94. Https://Doi.Org/10.33701/Jurnaltatapam ong.V1i2.1153.

Ansor, Muhammad. "Merayakan Kuasa Agama." Akademika: Jurnal Pemikiran Islam 22, no. 1 (2017):

103.

Https://Doi.Org/10.32332/Akademika.V

\section{2i1.562.}

Ansor, Muhammad, And Yaser Amri. "Being Christians In The Acehnese Way: Illiberal Citizenship And Women's Agency In The Islamic Public Sphere." Journal of Indonesian Islam 14, no. 1 (2020): 77-112. Https://Doi.Org/10.15642/JIIS.2020.14.1. $77-112$.

Artharini, Isyana. "Hukuman Cambuk Atas NonMuslim di Aceh, Dapat 'Menjadi Preseden dan Meluas." Wwm.Bbc.Com, 2016.

Asrun, Andi Muhammad, Abdu Rahmat Rosyadi, And Yennie K. Milono. "Mempertanyakan Legalitas Qanun Aceh: Sesuaikah dengan Sistem Peraturan Perundang-Undangan." Kanun Jurnal Imu Hukum 21, no. 2 (2019): 273-94.

Https://Doi.Org/10.24815/Kanun.V21i2. 12632.

Assembly, The General. "Universal Declaration of Human Rights (Chuukese)." Asia-Pacific Journal on Human Rights and The Law 8, no. 1 (2007):

101-6.

Https://Doi.Org/10.1163/1571815077822 00222.

Bagir, Zainal Abidin. Membatasi Tanpa Melanggar. Yogyakarta: Center For Religious And Cross-Cultural Studies, 2019.

Bagir, Zainal Abidin, Asfinawati, Suhadi, And Renata Arianingtyas. "Limitations to Freedom of Religion or Belief In Indonesia: Norms and Practices." Religion and Human Rights 15, no. 1-2 (2020): 39-56. Https://Doi.Org/10.1163/18710328BJA10003.

Bielefeldt, Heiner. "Freedom of Religion or Belief - A Human Right Under Pressure." Oxford Journal of Law and Religion, 2012. Https://Doi.Org/10.1093/Ojlr/Rwr018.

"Misperceptions of Freedom of Religion or Belief." Human Rights Quarterly 35, no. 1 (2013):

$33-68$. Https://Doi.Org/10.1353/Hrq.2013.0009.

. “'Western' Versus 'Islamic' Human Rights Conceptions? A Critique of Cultural Essentialism in The Discussion on Human Rights." Political Theory, 2000. 
Https://Doi.Org/10.1177/0090591700028 001005.

Black Donal. The Behaviour of Law. New York: Academic Press, 1976.

Bravo, Luisa. "We The Public Space. Strategies to Deal with Inequalities in Order to Achieve Inclusive And Sustainable Urban Environments." The Journal of Public Space 3, no. 1 (2018): 163-64. Https://Doi.Org/10.5204/Jps.V3i1.326.

Butt, Simon. "Religious Conservatism, Islamic Criminal Law and The Judiciary in Indonesia: A Tale of Three Courts." Journal of Legal Pluralism and Unofficial Law 50, no. 3 (2018):

402-34. Https://Doi.Org/10.1080/07329113.2018. 1532025.

Cempaka, Ali Abu Bakar, And Badrul Munir. "Sanksi Bagi Pelaku Zina." Petita: Jurnal Kajian Ilmu Hukum dan Syariah 3, no. 2 (2020). Https://Doi.Org/10.22373/Petita.V3i2.54.

Detiknews. "AKKBB: Pengesahan Qanun Jinayat di NAD Melanggar HAM," 2009.

Dw. "Dua Orang Pingsan Saat Eksekusi Cambuk di Aceh, Amnesty: Kejam dan Tidak Manusiawi," 2019.

Fadlia, Faradilla, And Ismar Ramadani. "The Qanun Jinayat Discriminates Against Women (Victims of Rape) in Aceh, Indonesia." Journal of Southeast Asian Human Rights 2, no. 2 (2018): 448. Https://Doi.Org/10.19184/Jseahr.V2i2.83 58.

Fakhriah, Efa Laela. "Kewenangan Mahkamah Syar'iyah di Aceh Dihubungkan dengan Sistem Peradilan di Indonesia." Jurnal Ilmu Hukum 12, no. 2 (2013): 23-36. Https://Jih.Ejournal.Unri.Ac.Id/Index.Ph p/JIH/Article/View/1814\%0Ahttps://Jih. Ejournal.Unri.Ac.Id/Index.Php/JIH/Articl e/Download/1814/1785.

Febriandi, Yogi, Muhammad Ansor, And Nursiti. "Seeking Justice Through Qanun Jinayat: The Narratives of Female Victims of Sexual Violence in Aceh, Indonesia." Qudus International Journal of Islamic Studies 9, no. 1
(2021):

103-40.

Https:/ /Doi.Org/10.21043/QIJIS.V9I1.80 29.

Hidayatullah. "Dua Non Muslim di Aceh Pilih di Cambuk," 2018.

Hrw. "Indonesia: Aceh's New Islamic Laws Violate Rights," 2014.

Humas. "11 Terdakwa Pelanggar Syariat Aceh Tamiang Dicambuk," 2021.

Irham, Muhammad. "Kedudukan Syariat Islam di Nanggroe Aceh Darussalam (NAD) dalam Sistem Hukum Nasional." Jurnal Mentari 12, no. 1 (2009): 34.

Ismail, Endri. "Analisis Yuridis Terhadap Legalitas Qanun Aceh No. 6/2014 Tentang Hukum Jinayat.” Kanun Jurnal Ilmu Hukum 20, no. 1 (2018): 123-48. Https://Doi.Org/10.24815/Kanun.V20i1. 9625.

Ismawardi, I. "Syari'at Islam dalam Lingkup Keberagaman Masyarakat Aceh." Bidayah: Studi Ilmu-Ilmu Keislaman 12, no. 2 (2019): 165-82.

Http:/ /Ejournal.Staindirundeng.Ac.Id/Ind ex.Php/Bidayah/Article/View/181.

Junaidi, Junaidi, Muhammad Rusdi Bin Muhammadiah, and Muhazir Muhazir. "Revitalisasi Penerapan Qanun Nomor 6 Tahun 2014 Tentang Hukum Jinayat di Kota Langsa Aceh.” Al-Manabij: Jurnal Kajian Hukum Islam 14, no. 1 (2020): 147-60. Https://Doi.Org/10.24090/Mnh.V14i1.32 61.

Kamali, Mohammad Hashim. "Qanun Jinayat of Aceh, Indonesia." In Crime and Punishment in Islamic Law, 2019. Https://Doi.Org/10.1093/Oso/97801909 10648.003.0024.

Krisna, L.A., I N. Nurjaya, P. Djatmika, and N. Aprilianda. "The Urgency of Harmonization of Offense Types in The Qanun Jinayat As an Effort to Avoid Dualism in Application of Law." Russian Journal of Agricultural and Socio-Economic Sciences 112, no. 4 (2021): 15-21. Https://Doi.Org/10.18551/Rjoas.202104.02 . 
Mahdi. "Sistem Hukum Penegakan Qanun Jinayah di Aceh." Media Syariab XIII, no. 2 (2011): 179-92.

Marzuki Suparman. Politik Hukum dan Hak Asasi Manusia. Erlangga, 2014.

Maulina, Putri. "Relasi Kekuasaan dalam Wacana Penerapan Qanun Jinayat di Aceh." Source: Jurnal Ilmu Komunikasi 3, no. 2 (2018). Https://Doi.Org/10.35308/Source.V3i2.6 58.

Melayu, Hasnul Arifin, Rusjdi Ali Muhammad, MD Zawawi Abu Bakar, Ihdi Karim Makinara, and Abdul Jalil Salam. "Syariat Islam dan Budaya Hukum Masyarakat di Aceh." Media Syari'ab: Wabana Kajian Hukum Islam dan Pranata Sosial 23, no. 1 (2021):

55. Https://Doi.Org/10.22373/Jms.V23i1.907 3.

Michael Feener, R. "Social Engineering Through Sharı: Islamic Law and State-Directed Da'wa in Contemporary Aceh." Islamic Law and Society, 2012. Https://Doi.Org/10.1163/156851911X61 2581.

Misran, - -. "Sosialisasi Qanun Jinayat Aceh No. 6 Tahun 2014 Pada Madrasah Aliyah Blangkejeren Kabupaten Gayo Lues." Dusturiyah: Jurnal Hukum Islam, PerundangUndangan dan Pranata Sosial 9, no. 1 (2019): 15.

Https://Doi.Org/10.22373/Dusturiyah.V9 i1.4365.

Mubarrak, Husni, and Intan Dewi Kumala. "Diskriminasi terhadap Agama Minoritas: Studi Kasus di Banda Aceh." Seurune Jurnal Psikologi Unsyiah 3, no. 2 (2020): 42-60. Https://Doi.Org/10.24815/SJpu.V3i2.17553.

Mudzakkir, Amin. "Islam dan Politik di Era Kontemporer." Epistemé: Jurnal Pengembangan Ilmu Keislaman 11, No. 1 (2016). Https://Doi.Org/10.21274/Epis.2016.11. 1.31-48.

Nurdin, Ridwan. "Kedudukan Qanun Jinayat Aceh dalam Sistem Hukum Pidana Nasional Indonesia." Miqot: Jurnal Ilmu-Ilmu Keislaman
42, no. 2 (2019): 356. Https:/ /Doi.Org/10.30821/Miqot.V42i2.5 42.

Nurdin, Ridwan, And Muhammad Ridwansyah. "Aceh, Qanun And National Law: Study on Legal Development Orientation." Samarah 4, no. 1 (2020): 107-31. Https://Doi.Org/10.22373/Sjhk.V4i1.641 6.

Nurozi, Ahmad, and Dadan Muttaqien. "The Effectiveness of Crime Prevention With Corporal Punishment in Nanggroe Aceh Darussalam." Millah: Jurnal Studi Agama 20, no. 2 (2021): 223-44. Https://Journal.Uii.Ac.Id/Millah/Article/ View/14771.

Pemprov Aceh. "Qanun Jinayat No.6 Tahun 2014,” N.D.

Praja, Selvia Junita, and Wia Ulfa. "Implementasi Qanun Nomor 6 Tahun 2014 Tentang Hukum Jinayat di Kota Banda Aceh Provinsi Aceh." Jurnal Kebijakan Pemerintahan 3, no. 2 (2020): 11-20. Https://Doi.Org/10.33701/Jkp.V3i1.1071.

Putra, Heru Permana, and Desi Syafriani. "Otonomi Daerah dan Pengaruhnya Terhadap Kebijakan Daerah Bernuasa Syariah di Kota Padang." Islam Transformatif: Journal of Islamic Studies 3, no. 2 (2019): 118. Https://Doi.Org/10.30983/It.V3i2.2417.

Rahman, Abdul. "Sistem Pemerintahan Berbasis Syariat Islam di Indonesia (Studi Kasus Penerapan Qanun Jinayat di Pemerintah Provinsi Aceh)." KAIS Kajian Ilmu Sosial 2, no. 2 (2020): 91-107.

Rahmiati, Rahmiati. "Politik Hukum Terhadap Qanun Nomor 6 Tahun 2014 Tentang Hukum Jinayah.” SASI 26, no. 1 (2020): 29. Https://Doi.Org/10.47268/Sasi.V26i1.209

Rochaeti, Nur, and Rahmi Dwi Sutanti. "Kontribusi Peradilan Adat dan Keadilan Restoratif dalam Pembaruan Hukum Pidana di Indonesia." Masalah-Masalah Hukum, 2018.

Https://Doi.Org/10.14710/Mmh.47.3.201 8.198-214. 
Sahara, Siti, and Meta Suriyani. "Efektifitas Penghukuman Bagi Pelaku Maisir (Perjudian) di Kota Langsa." Jurnal Hukum Samudra Keadilan 13, no. 1 (2018): 118-38. Https://Doi.Org/10.33059/Jhsk.V13i1.69 7.

Sari, Cut Maya Aprita. "Pro dan Kontra Implementasi Qanun Syariat Islam di Aceh.” Jurnal Review Politik 6, no. 01 (2016): 68-89.

Https://Www.Researchgate.Net/Profile/C ut-Maya-Aprita-

Sari/Publication/342831406_Pro_dan_Ko ntra_Implementasi_Qanun_Syariat_Islam_ di_Aceh/Links/5f07e31c92851c52d6268da f/Pro-dan-Kontra-Implementasi-QanunSyariat-Islam-di-Aceh.Pdf.

Seedat, Fatima. "Sexual Economies of War And Sexual Technologies of The Body: Militarised Muslim Masculinity and The Islamist Production of Concubines or The Caliphate." Agenda 30, no. 3 (2016): 25-38. Https://Doi.Org/10.1080/10130950.2016. 1275558.

Setiawan, Deni, Universitas Muhammadiyah Yogyakarta, Zuly Qodir, Universitas Muhammadiyah Yogyakarta, Hasse Jubba, And Universitas Muhammadiyah Yogyakarta. "Pro-Kontra Kebijakan Syariat Islam di Bumi Serambi Mekkah." Dialektika: Jurnal Pemikiran Islam dan Imu Sosial 13, no .1 (2020): 22-37.

Siregar, Hasnil Basri. "Islamic Law In A National Legal System: A Study on The Implementation of Shari'ah in Aceh, Indonesia." Asian Journal of Comparative Law 3, no. 1 (2008): 1-14. Https://Doi.Org/10.2202/19320205.1056.

"Lessons Learned from The Implementation of Islamic Shari'ah Criminal Law in Aceh, Indonesia." Journal of Law and Religion 24, no. 1 (2009): 23-35.

Stanford, Ben. "Power to The People? Public Spaces Protection Orders, Hybrid Law And Human Rights." SSRN Electronic Journal 12, no. 2 (2019): 234. Https://Doi.Org/10.2139/Ssrn.3442435.
Suparmin, Sudirman. "Hukuman Cambuk Terhadap Non Muslim Pelaku Jarimah di Nanggroe Aceh Darussalam." Analytical Islamica 6, no. 2 (2017): 147-54.

Susantri, Yulia, And Roni Hidayat. "Perda, Qanun, dan Perdasi dalam Sistem Hukum Nasional." Syiah Kuala Law Journal 4, no. 1 (2020): Https://Doi.Org/10.24815/Sklj.V4i1.1659 5.

Sweetman, Brendan. "Equality, Freedom And Religion." The Philosophical Quarterly, 2016, Pqw033.

Https://Doi.Org/10.1093/Pq/Pqw033.

Syafi'ie, M. "Pemikiran Organisasi Islam Tentang Penerapan Hukum Pidana Islam: Tinjauan Hukum Hak Asasi Manusia." Undang: Jurnal Hukum 2, no. 2 (2020): 225-64. Https://Doi.Org/10.22437/Ujh.2.2.225264.

Tempo. "Qanun Jinayat Aceh Juga Berlaku Untuk Non-Muslim,” 2014.

Thalib, Prawitra. "Pemahaman Terhadap Pemberlakuan Hukum Islam di Indonesia." Halu Oleo Law Review 2, no. 1 (2018): 371. Https://Doi.Org/10.33561/Holrev.V2i1.4 196.

Ulya, Zaki. "Dinamika Penerapan Hukum Jinayat Sebagai Wujud Rekonstruksi Syari'at Islam di Aceh." Jurnal Rechts Vinding: Media Pembinaan Hukum Nasional 5, no. 1 (2016): 135-48.

Https://Www.Rechtsvinding.Bphn.Go.Id/ Ejournal/Index.Php/Jrv/Article/View/9.

Wicaksono, Dian Agung, and Ola Anisa Ayutama. "Pengaturan Hukum Cambuk Sebagai Bentuk Pidana dalam Qanun Jinayat." Majalah Hukum Nasional 48, no. 1 (2018):

25-37. Https://Doi.Org/10.33331/Mhn.V48i1.11 1.

Yuhermansyah, Edi, and Meri Andani. "Tanggapan Masyarakat Kecamatan Pulau Banyak terhadap Pemberlakuan Qanun Nomor 6 Tahun 2014 tentang Hukum Jinayat." Legitimasi: Jurnal Hukum Pidana dan Politik Hukum 7, no. 1 (2018): 43. Https://Doi.Org/10.22373/Legitimasi.V7i 
1.3964.

Zainuddin, And Sahban. "Problematics of Jinayat Qanun Implementation in Nanggroe Aceh Darussalamn Community." Tadulako Law Review 3, no. 1 (2018): 221-34. Http://Jurnal.Untad.Ac.Id/Index.Php/TL $\mathrm{R}$.
Zuhra, Nadia Maulida. "Penerapan Hukuman Cambuk Bagi Pelaku Pelecehan Seksual dalam Perkara Jinayat Dihubungkan dengan Jaminan Akan Hak Asasi Manusia Atas Rasa Aman dan Perlindungan Bagi Korban." DiH: Jurnal Ilmu Hukum 16, no. 2 (2020): 259-70.

https://doi.org/10.30996/dih.v16i2.3668. 